Book Review

\title{
A New Myth of Humanity
}

\author{
Robert Atkinson
}

University of Southem Maine

Rollo May, The Cry for Myth. New York: Norton, 1991. \$22.95.

The link between psychoanalysis and myth is a bridge that Rollo May has been building for a long time. This long-awaited book pulls together his intriguing thoughts on why myth is so important in our lives today, both individually and collectively. We end up, after reading his discussions on the functions of myth, myths in America, and myths of the Western world, with a clear picture of what he feels are the myths that will ensure our personal and global survival. This has everything to do with our understanding the healing power of myth, and living according to "a new myth," through which we may achieve "the sacramentalizing of the planet."

Rollo May finds that contemporary therapy is almost entirely concerned with the problems of the individual's search for myths. He says, "I believe there is an urgency in the need for myths in our day. Many of the problems of our society, including cults and drug addiction, can be traced to the lack of myths which will give us as individuals the inner security we need in order to live adequately in our day." Without viable, living myths to serve as guideposts for our life, we end up with a loss of identity, depression, chaos, and aggression. May's attempt in this book is "to show how myths can be rediscovered as tools for understanding ourselves."

Myth is a difficult term to define. The problem exists mainly because it is used more often to mean the exact opposite of what it really is. People are more used to thinking of myth as a falsehood than as an essential truth. May offers a number of ways of understanding what a myth is: "myths are narrative patterns that give significance to our existence... myths are our way of finding this meaning and significance... myths are like beams in a house: not exposed to outside view, they are the structure which holds the house together so people 
can live in it... the myth is a drama which begins as a historical event and takes on its special character as a way of orienting people to reality. The myth, or story, carries the values of the society: by the myth the individual finds his sense of identity... myth refers to the quintessence of human experience."

Myth, then, conveys "an eternal truth" which does not change with the latest discoveries; the truth myth speaks of transcends time and space. Myth conveys what is collectively true for all human beings. That is why "myth making is essential in gaining mental health," and "central in psychotherapy." Each individual must undertake the process of discovering who they are in relation to all others. This is what happens during personal myth making.

When the guiding myths of a society break down, as they did in classical Greece during the third and second centuries we see the kind of thing Lucretius observed, "aching hearts in every home" and incessant "pangs the mind was powerless to assuage." This is where we are today, again, and what has created "the lonely search for internal identity," and the need for personal myth making, or rediscovering personal meaning and finding our place in the world. For this need did psychotherapy come into existence, along with "the multitude of cure-alls and cults, constructive or destructive as they may be."

The need for communal and personal myths are equally important. On a collective level, myths give us the eternal verities and values that guide society. "They are narrations by which our society is unified."

We also need our own personal version of these narratives to help keep our inner self unified. May says, "myths are our self-interpretation of our inner selves in relation to the outside world... myths are essential to the process of keeping our soul alive and bringing us new meaning in a difficult and often meaningless world." This is what people do when they come to therapy, or when they really follow their own fantasies, they create personally relevant narratives that add meaning to their own particular circumstances and $\mathrm{ex}^{-}$ periences. These personal narratives "bring some order and coherence into the stream of sensations, emotions, and ideas" entering our consciousness from within or without. It is of the utmost importance that we take our own myths seriously.

In a strong but unacknowledged, parallel to Joseph Campbell's four functions of myth, May says that myths give us our sense of personal identity; our sense of community; they undergird our moral values; and offer a way of dealing with the inscrutable mystery of creation. This is a lot for a myth to do, but they can do all this because myths carry within their storyline, or basic structure and pattern, elements common to human experience and consciousness everywhere that are called archetypes. These are motifs, or smaller elements of the story, that speak of universally human experience or emotion. 
These are really original revelations or expressions, of the collective unconscious, as Jung would say.

Archetypes are the smaller elements within myths that give them their universally valid meaning. Archetypes include any of the common human experiences that any or all of us can experience at any time in our lives. They reflect in some shape or other the themes of birth and death, aloneness and unity, love and animosity, productivity and stagnation, and countless other possible essentially human themes. Therefore, myths, which carry these motifs within them, are necessary links between physical and spiritual human beings. The interesting thing is that we all have access to these archetypes whether or not we are familiar with them; "archetypes are the structure of human existence," says May. Myths, and the archetypes within them, really describe a lived experience. Great dramas, too (May uses the examples of Hamlet, Macbeth, and Death of a Salesman), express mythic themes in this way; they also describe real life, essentially human possibilities.

- One of the more powerful assertions May makes that really seems to strike a resonant chord is that "the person without a myth is a person without a home." A sense of "home" gives us not only a place to call our own, but an identity to call our own, too. Alex Haley writes in Roots, "I had to find out who I was." Oedipus in Oedipus Rex says, "I must find out who I am and where I came from." Having a sense of past, whether that is a place or a set of beliefs or both, is crucial to having a present identity and a future to live for. Discovering our own myth gives us the identity we seek, and the sense of belonging we need. Myth making is meaning making; having both a myth and meaning in life is having a home, a sense of community. "Our powerful hunger for myth is a hunger for community," May says.

One of the things that will help us discover and take our own myth seriously is to become familiar with other myths that can then serve as mirrors to our experience. Rather than provide examples of these possible mirrors for us from oriental mythology, as he says Joseph Campbell has already done, May does an interesting and novel thing by offering "myths of our own America" to reflect on. We probably are more used to thinking of American "myths" as falsehoods. But what May does is discuss "the myth of the frontier," "the myth of Horatio Alger," and "Gatsby and the American Dream" in terms of their archetypal patterns and mythic motifs. If we are comfortable with stretching the definition of myth a bit to include this more recent material, May is quite convincing in showing us how and why these ideas and pieces of American literature do carry "an eternal truth" within them. They are stories through which we find values, identity, and the quintessence of human experience. He does a similar thing with some of the "myths of the Western world," referring 
to the work of Dante, Virgil, Ibsen, a Grimm brother's fairy tale, Goethe, and Melville. Here, again, he identifies the timeless and universal themes that make up the archetypal pattern of personal discovery and transformation.

What I find most valuable in Rollo May's carcer capping work comes in the last chapter. After explaining well what in these myths are important to us today, and why the Faustian myth of patriarchal power, with its symbol of the straight line, always moving ahead in competition and material progress, is no longer appropriate, May offers a different symbol for our time, "the great circle of love."

He goes on to explain one of the "myths for survival": "the myth of the equality of men and women." This is not a myth in the popular sense of a falsehood. This myth is one of those eternal truths that we are just now, finally, coming to understand as a universal human value. In all of the myths that he discusses, May points out how the climactic deed was always accomplished only when there was a balance of feminine and masculine qualities evident. When this was lacking, something prevented the task at hand from being completed. May puts it this way, "In each of these dramas the liberation of both woman and man is possible only when each achieves a new myth of the other sex, leading to a new significant psychological relationship. They are both then liberated from their previous empty and lonely existence. The woman and the man find their true selves only when they are fully present to each other." It is a matter of both needing each other, not just physically but psychologically and spiritually. This is liberation, and this is when we are all free to be what we inherently are.

When we have really learned this one, and are able to live this myth of equality, we will be able to understand and begin to live the other myth for survival: "the myth of humankind." This verity that we are also just now coming to understand represents our sense of belonging, and community, on the grandest, most profound level. Since those remarkable photographs of the earth came back to us from the moon, life has never been the same, according to May, Archibald MacLish, the astronauts, and many others. We have been able to see that we "are truly brothers." By exploring this new myth of planetism and humanhood, May believes, "we can achieve a new international ethics and understanding, a new raison d'etre for humanity." Our home, our community, is a "new world" where we are all neighbors, "at least in the same family." This is where we find our identity, our myth that is alive and vital, today.

This is not a new idea. The astronauts, and other seers throughout time, who have spoken of our inherent unity have done so out of personal experience, but they also say it is an experience available to all. Rollo May takes us on a remarkable journey in this book, from "the passion to find our home," to 
"planetism and humanhood." He has helped make the idea of "the myth of humanity" more real and personal for us. It is easier to understand now why "we all cry for a collective myth which gives us a fixed spot in an otherwise chaotic universe."

Robert Atkinson, Ph.D., Associate Professor of human development and director of the Center for the Study of Lives at the University of Southern Maine, is the author of The Life Story Book: From Autobiography to Personal Myth, to be published by Ballantine Books in 1992. Address correspondence to: Robert Atkinson, Center for the Study of Lives, University of Southern Maine, Gorhan, ME 04038. 